\title{
„SOUKROMÉ JE POLITICKÉ“: FEMINISTICKÉ STŘíPKY Z ČESKOSLOVENSKÉHO UMĚNÍ ŠEDESÁTÝCH AŽ OSMDESÁTÝCH LET DVACÁTÉHO STOLETÍ
}

\author{
MARIANNA PLACÁKOVÁ \\ Ústav pro dějiny umění Filozofické fakulty Univerzity Karlovy \\ marianna.placakova@gmail.com
}

\begin{abstract}
"The Personal is Political": The Feminist Fragments of Czechoslovak Fine Arts 1960s-1980 s

The aim of this article is to show examples of feminist art in relation to contemporary gender policies and political situation in socialist Czechoslovakia from the 1960s to the 1980s. Czechoslovak gender policies that enabled women to access employment opportunities in the 1950s simultaneously led to their high over-employment that was not resolved during the period of state socialism. The conflicting relationship between the role of mother and working woman therefore became one of the main topics of the feminist art production of that time.
\end{abstract}

Keywords: Feminism - women's emancipation - state socialism - Czechoslovakia - feminist art

Konflikt mezi postavením ženy ve veřejném a soukromém prostoru je základní téma agendy feministického hnutí, které je doprovází od počátků jeho vzniku v devatenáctém století až dodnes. Heslo „soukromé je politické“ se stalo v šedesátých letech hlavním mottem druhé vlny feminismu, která ve své činnosti navazovala na silnou tradici svých předchůdkyň. Takzvaná první vlna se snažila především o prosazení právní rovnosti pohlaví (například zavedením volebního práva pro ženy) a o lepší přístup žen ke vzdělání. $\mathrm{V}$ šedesátých letech podrobovalo feministické hnutí kritice zvláště společenskou praxi, která se s rovnoprávným genderovým pojetím rozcházela. Ve Spojených státech amerických, v nichž se druhá vlna feminismu zrodila, byla jedním z hlavních témat kritika společenského postavení ženy, zploštující ji na roli matky a ženy v domácnosti, která vytváří a udržuje obraz spokojené americké rodiny.

Tradiční model, který viděl ženu především v roli matky a ženy v domácnosti, se státní genderová politika v socialistickém Československu snažila v padesátých letech vymýtit. Podle marxistického pojetí bylo k dosažení genderové rovnoprávnosti zapotřebí nejen právní rovnosti, ale i ekonomické nezávislosti ženy na muži a převzetí domácích prací společností. ${ }^{1} \mathrm{~V}$ padesátých letech byla proto silně propagována pracovní role ženy.

1 Bedřich Engels, Původ rodiny, soukromého vlastnictví a státu, Praha 1967, s. 26. 
O dekádu později se tento model začal revidovat a objevily se diskuze o konfliktu mezi mateřskou a zaměstnaneckou rolí ženy. ${ }^{2}$ Pozitivně hodnocená kolektivní výchova dětí v jeslích byla problematizována společně s novými poznatky z dětské psychologie o primární socializaci dítěte. Stejně tak kolektivistická zařízení, jako např́iklad závodní jídelny nebo Osvobozená domácnost, jež měla převzít domácí práce, nebyla v padesátých letech nikdy ve velkém prosazena a kvůli nízké kvalitě se od jejich užívání upouštělo. ${ }^{3}$

Podle různých statistik trávily ženy v šedesátých letech průměrně okolo pěti hodin denně prací v domácnosti (v závislosti na jejím technickém vybavení). Nejvíce času jim kvůli většinovému stravovacímu zvyku teplé večeře zabíralo vaření. ${ }^{4}$ Toto velké pracovní vypětí žen (tzv. trojí břemeno), které zahrnovalo práci, péči o domácnost a o děti, v protikladu $\mathrm{k}$ mužům, kteří se na domácích pracích téměř nepodíleli a měli o mnoho víc volného času i doby na spánek, bylo předmětem kritiky a diskuze odborníků. Ačkoli byla problematizována složitá situace postavení žen, její řešení se nehledalo v rovnoprávném rozdělení domácích prací mezi pohlavími. Problém přezaměstnanosti žen měl vyřešit technický pokrok v podobě zdokonalení dopravy do zaměstnání, odstranění front v potravinářských obchodech a provozovnách služeb, rozvoj polotovarů a hotových jídel, vybudování husté sítě technicky dokonalých velkoprádelen a čistíren. ${ }^{5}$ Kritika domácí práce žen nezaznívala jen $\mathrm{z}$ řad sociologů, psychologů, ekonomů, ale od začátku šedesátých let se objevovala i v dílech československých umělkyň.

\section{Pleny, guláš, kondomy}

Srovnávání československého poválečného umění s uměním, které v té době vznikalo na Západě, se v českém dějepisu umění děje většinou na základě komparace obdobných výtvarných forem, u nichž se v kontextu socialistické společnosti interpretuje odlišný obsah (například kniha Srovnávací studie Tomáše Pospiszyla ${ }^{6}$ ). Cílem tohoto příspěvku je zvolit opačnou interpretační cestu, a sice hledat obdobná obsahová témata v odlišně formálně pojatých výtvarných dílech. $\mathrm{V}$ tomto př́ípadě se jedná o komparaci mezi československým a západním feministickým uměním. Na Západě začaly umělkyně na začátku sedmdesátých let používat odlišné vyjadřovací formy než ty, které byly doménou umělců-mužů (abstraktní expresionismus). Pracovaly s videoartem, který působil subverzivně vůči profesionalismu filmového a televizního průmyslu, a vytvářely performance, happeningy a kolektivní akce obsahující aktivistický rozměr. V Československu tento kolektivní rozměr feministického umění neexistoval. Po roce 1948 byly socialistickým státem ženské spolky zakázány a politický aktivismus byl mimo rámec státní politiky nemožný. Tvorba československých umělkyň měla individualistický charakter, který vycházel z opozice vůči státnímu pojetí organizace zastupující práva žen - Československé-

2 Marianna Placáková, Člověk, nebo sexus? Diskuze k českému vydání knihy Simone de Beauvoir „Druhé pohlaví, Filosofický časopis LXVIII, 2020, č. 6, s. 865-886.

3 Barbara Havelková, Tři stadia genderu v socialistickém právu, in: Hana Havelková - Libora Oates-Indruchová (eds), Vyvlastněný hlas. Promèny genderové kultury české společnosti 1948-1989, Praha 2015, s. 45-82.

4 Alena Wagnerová, Žena za socialismu [1974], Praha 2017, s. 142.

5 Radoslav Selucký, Ekonomika, morálka, život, Praha 1963, s. 41.

6 Tomáš Pospiszyl, Srovnávací studie, Praha 2005. 
ho svazu žen. Zároveň se většina z nich držela tradičních forem umění - malby, grafiky a tvorby objektů. Video-art byl v Československu kvůli těžké dosažitelnosti techniky výjimečnou záležitostí a objevoval se většinou až ke konci pozdního socialismu v podobě formálních experimentů.

Přes nepř́iznivé politické okolnosti zde na přelomu šedesátých a sedmdesátých let vzniklo několik akcí, jež by se daly označit za feministické. V květnu 1970 uspořádala Zorka Ságlová akci Kladení plín u Sudoměre. Společně se svými přáteli rozložila na místě historické bitvy asi 700 čtverců bílé tkaniny, které vyskládala do tvaru velkého trojúhelníku a zanechala je tam. ${ }^{7}$ Ten samý měsíc se konala v Galerii Václava Špály výstava Naděždy Plíškové, na jejíž vernisáž autorka uvařila 7 litrů gulášové polévky, kterou naservírovala do jednoho ze svých objektů - obrovské hliníkové lžíce. Návštěvníci společně s autorkou během vernisáže obsah lžíce zkonzumovali. V obou akcích umělkyně tematizovaly domácí práce žen a vycházely v nich ze své osobní zkušenosti - vaření a v případě Ságlové praní a sušení plen, s kterým se tehdy jako matka roční dcery každodenně potkávala. Ačkoli se jednalo o kolektivní akce, nebylo jejich cílem vzbuzovat emancipační vědomí jejich účastnic, jako tomu bylo v sedmdesátých letech například při performancích probíhajících během feministického programu California Institute of the Arts. Účastníky akcí byli genderově smíšené skupiny - u Ságlové okruh lidí z undergroundové hudební skupiny The Plastic People of the Universe, v případě Plíškové okruh Křižovnické školy čistého humoru bez vtipu. V kontextu politické situace roku 1970, kdy docházelo k omezování různorodé umělecké produkce státní kulturní politikou, byl pro tyto akce důležitý faktor společenství lidí držících pohromadě, zážitek „euforie, humoru a pospolitosti“. 8

Dalším specifikem těchto akcí byla jejich materiální stránka spojená s estetikou. Značná část západních feministických akcí tematizovala „ženskou práci“ právě jejím subverzivním předváděním ve veřejných kontextech. Americká umělkyně Mierle Laderman Ukeles například během své performance několik hodin vytírala schody před vstupem do galerie (Hartford Wash: Washing/Tracks/Maintenance (Outside), 1973) a Němka Renate Eisenegger žehlila pravoúhlé a liduprázdné chodby hamburského mrakodrapu (Hochhaus (Nr. 1), 1974). ${ }^{9} \mathrm{~V}$ těchto akcích umělkyně problematizovaly repetitivnost, nekonečnost a neviditelnost „ženské práce“. Uměleckým aktem pro ně byla akce sama o sobě, z níž nevznikl žádný materiální produkt. Oproti tomu akce Plíškové a Ságlové jsou na materialitě založeny. Zorka Ságlová vztahovala své akce „k materiálu, místu, živlùm“10. $\mathrm{V}$ př́padě Kladení plín u Sudoměre sestavila útržky textilu do geometrického obrazce, jenž vycházel z estetiky nové citlivosti šedesátých let, a vytvořila tak land-artovou plastiku. Plišková zase nalila uvařenou polévku (během zmíněné vernisáže) do jednoho ze tř́ objektů dvoumetrových lžic, které byly inspirované estetikou pop-artu. To, že pro ni objekt lžíce byl důležitý ve srovnání se samotnou akcí př́ípravy a konzumace polévky, svědčí

7 Další z děl komentujících „ženskou práci“ byla instalace Zorky Ságlové na výstavě v Ústavu makromolekulární chemie ČSAV v Praze v roce 1989, kdy textilní obrazy králíků, autorčiny osobní ikonografie, byly rozvěšeny na šňưře tak, jako se suší prádlo. Srov. Lenka Bučilová, Zorka Ságlová. Úplný přehled díla, Praha 2009, s. 36.

8 Karolína Jirkalová, Věra Jirousová: Hned jsem věděla, že máme vystoupit, Art+Antiques, 2009, 6. 3., http://artcasopis.cz/clanky/hned-jsem-vedela-ze-mame-vystoupit, vyhledáno 10. 12. 2016.

9 Gabriele Schor, Feministische Avantgarde. Kunst der 1970er-Jahre. Sammlung Verbund, Wien 2016, s. 347.

10 Věra Jirousová, Rozhovor se Zorkou Ságlovou, Výtvarné umění IV, 1993, č. 1, s. 49. 
i to, že v dobovém výstavním katalogu je akce zahrnuta pod popis samotného objektu: název 7 litrů gulášové polévky, 1969-1970, hliník, nerez, ocel, hovězí maso přední, cibule, tuk, sladká paprika, brambory, rajský protlak, sůl.

Pro akce československých umělkyň bylo rovněž typické, že v sobě skrývaly více obsahových plánů. Kromě kritiky „ženské práce“, vycházející ze společenské reality, pracovala Ságlová ve své akci s národní legendou, kdy symbolicky znovuzinscenovala mýtus o husitských ženách, které pomohly zvítězit svým mužům v bitvě tím, že zakryly textiliemi mokřinu, do níž nepřátelské vojsko zapadlo. Inspirace mýty či českou historií můžeme vidět i u dalších neoficiálních akcí té doby, jež byly součástí dobového romantického obratu ke kořenům české tradice stojící v protikladu k tehdejší společensko-politické realitě. Zároveň použití této legendy mohlo být symbolickým odkazem ke kolektivnímu ženskému aktivismu ${ }^{11}$ (husitským hnutím se mimo jiné inspirovala i první vlna feministek v českých zemích ${ }^{12}$ ). U Naděždy Pliškové se dá v akci 7 litrů gulášové polévky kromě kritiky „ženské práce“ najít i kritika konzumní společnosti, která v Československu, byt” v omezené formě, přece jen existovala. ${ }^{13}$ Plíšková, pro níž byl jedním z hlavních principů tvorby sarkasmus, ironizovala ve svém díle nesčetněkrát konzumerismus československé společnosti právě ve vztahu k jídlu (grafika Vepřové kotlety př́rodní z roku 1969, kresba Knedlik základ rodiny, 1982).

Podobně jako v ostatních socialistických státech existoval v Československu rozdíl mezi akčním uměním mužů a žen. ${ }^{14}$ Pokud se podíváme na jeho hlavní československé představitele sedmdesátých let - Karla Milera, Jana Mlčocha, Petra Štemberu -, zjistíme, že se ve své tvorbě, inspirováni existencialismem a zenovým buddhismem, zabývali tématy, jako jsou fyzické a psychické limity lidského těla, a řešili univerzální otázky podstaty lidské existence. Oproti nim akce umělkyň, které pravděpodobně na tak „sofistikovaná“ témata neměly čas, pracovaly ve srovnání se svými kolegy o dost více s předměty vycházejícími z jejich každodenní zkušenosti, v nichž tematizovaly ženskou práci nebo pozice ženy ve společnosti. ${ }^{15}$ Tyto akce umělkyním zároveň sloužily jako platforma k vyjádření dobového nerovného postavení žen (např. trojího břemene).

\section{Poezie, objekt, textil, malba}

Akční umění bylo u československých umělkyň spíše okrajovou záležitostí. Zajímavé jsou v tomto ohledu dobové texty a poezie, z nichž se některé formálně i obsahově po-

11 Srov. Martina Pachmanová, Laying Diapers, Loving Nature: Maternity as a Private Act and Political Gesture, in: Katja Kobolt - Lana Zdravkovič (eds), Performative Gestures. Political Moves, Záhřeb 2014, s. 63.

12 Srov. Teréza Nováková, Ze ženského hnutí, Praha 1912.

13 Srov. Paulina Bren, Zelinář a jeho televize. Kultura komunismu po pražském jaru 1968, Praha 2013.

14 Srov. Piotr Piotrowski, The Politics of Identity: Male and Female Body Art, in: Piotr Piotrowski, In the Shadow of Yalta. Art and the Avant-garde in Eastern Europe, 1945-1989, London 2011, s. 341-387. Amy Bryzgel, Performance art in Eastern Europe since 1960, Manchester 2017.

15 S prezervativy pracovala Zorka Ságlová během kolektivní akce Pocta Fafejtovi, která se konala v říjnu 1972 na tvrzi Vř́ísek u České Lípy. Účastníci vytvořili environment $\mathrm{z}$ nafouknutých prezervativů, které rozfoukal vítr. Akce ironicky komentovala pronatalitní politiku socialistického státu, která byla zaváděna s nástupem tzv. normalizace. Srov. Franziska Lesák, Na místě. V rozhovoru se čtyřmi aktéry samizdatu (Věra Jirousová), Praha 2013, s. 24. 
dobaly literárním scénářům $\mathrm{k}$ happeningům a manifestům západních umělkyň. Ukeles např́íklad sepsala po zážitku narození prvního dítěte v roce 1969 manifest Maintenance Art (Umění péče), v němž upozorňovala na malé ekonomické i symbolické ohodnocení domácí práce společností. Manifest byl napsán formou dlouhého seznamu úkonů pro udržení chodu domácnosti a zaopatření dítěte. Podobně i poezie Naděždy Pliškové, kterou začala psát na přelomu padesátých a šedesátých let, byla založena na principu výčtů úkonů v domácnosti, jejichž dlouhé seznamy měly evokovat nekonečnost a repetitivnost této práce. Básně Naděždy Plíškové psané v ich-formě, v nichž se vymezovala vůči pozici svého muže v domácnosti, v sobě také obsahovaly kritický osten vưči tehdejším společenským normám. ${ }^{16}$

Jednou z častých výtvarných forem československých umělkyň té doby byl objekt. Kromě Zorky Ságlové byla novou citlivostí ovlivněna také Běla Kolářová, která ale geometričnost této tendence již od počátku dekonstruovala používáním každodenních předmětů $\mathrm{z}$ domácnosti. Často se jednalo o odpad vzniklý $\mathrm{z}$ autorčiny péče o domácnost a její práce v kuchyni. ${ }^{17}$ Tyto práce se kromě svého ekologického rozměru dají chápat i jako obrazové deníky, či reportáže z autorčina dne, které trávila v domácnosti. Z roku 1966 pochází cyklus objektů Nádobí, v němž Kolářová zasadila různorodé předměty - sklíčka, perly, zátky od zubní pasty, rybářské návnady, krabičky od sirek - do plátů skla a instalovala je v odkapávači. V této práci autorka nejenže dekonstruovala abstraktní geometrické struktury použitím předmětů z každodenního světa, zároveň je i zasadila do kontextu plastového odkapávače na nádobí - symbolického ztělesnění domácí „ženské práce“, kterého v šedesátých letech vlastnila každá rodina. ${ }^{18}$

V sedmdesátých letech se jeden ze směrů západního feministického umění pokoušel o rehabilitaci tvorby spojené s textilem, šitím a vyšínáním, prací tradičně chápaných jako nízké, femininní umění. Zároveň to byl počátek kolaborativních projektů, na nichž se podílely desítky žen a jejichž cílem bylo dosažení společenských změn. ${ }^{19} \mathrm{~V}$ Československu takováto forma kolaborativních projektů neexistovala. „Neoficiální“ umělkyně pracovaly s textilem na individuální rovině, současně ho ale používaly novými způsoby a ve své tvorbě se zabývaly rovněž různými druhy feminity. S textilem pracovala, ovlivněna pop-artem a novým realismem, Klára Bočkayová, která od konce šedesátých let začala sbírat „kuchařky“ - tradiční kusy bílého plátna, na nichž byla v ploše kromě figurálního výjevu vyšita „lidová moudrost“. Metodou frotáže je přenášela na papír pomocí roztírání akrylové barvy špachtlí na plátno, což jí umožnilo předlohy různým způsobem násobit a měnit. Formou citací, která v sobě zahrnovala rysy postmoderního myšlení, Bočkayová dekonstruovala obrazy maloměštáctví, tradiční rodiny a obrazové sentimentality. Zároveň svými citacemi přejímala a upozorňovala na díla anonymních žen několika generací. Z roku 1980 pochází cyklus Poslední večeře, v němž citovala, podobně jako mnoho západních feministických umělkyň (např́klad Mary Beth Edelson, Some Living American Woman Artists, 1972), obraz Leonarda da Vinci. Častá reinterpretace tohoto obrazu vznikala nejen díky jeho

16 Naděžda Plíšková, Plíšková podle abecedy, Praha 1991.

17 Marie Klimešová, Experiment, řád, dưvěrnost. Ženské rastry Běly Kolářové (katalog výstavy), Muzeum umění Olomouc 2006, s. 11.

18 Alice Motard - Marie Klimešová, Běla Kolářová (katalog výstavy), Raven Row 2013.

19 Norma Broude - Mary D. Garrard (eds), The Power of Feminist Art. The American Movement of the 1970s, History and Impact, New York 1996, s. 66-73. 
ústřední pozici v kánonu dějin umění, ale pravděpodobně také díky androcentrické povaze Nového zákona. Bočkayová se tak ve své frotáži postavením ženy-kuchařky a mužů-stolovníků vedle sebe ironicky tázala po tradičním chápání genderových rolí v domácnosti. ${ }^{20}$

V Československu pracovala s textilem také Mira Haberernová, která od roku 1967 vytvářela měkké látkové plastiky lidské velikosti. Došla k nim skrze své asambláže, inspirované Dubuffetem a Tapiésem, v nichž používala kusy oblečení. Plastiky, jimž říkala loutky, instalovala na výstavách do trojrozměrných obydlí a nechávala je návštěvníky galerie přenášet a hrát si s nimi, čímž instalace dostala performativní rozměr. Forma plastik, kterým autorka říkala panenky, odkazovala na archetyp ženy. Ten byl současně se zájmem o primitivní matriarchální kultury hlavním tématem jednoho z proudů západního feminismu. ${ }^{21} \mathrm{~V}$ případě Haberernové se nejednalo o vědomý politický program, ale spíše intuitivní př́ístup, vycházející z její zkušenosti. Provedení a materiál objektů odkazovaly k socialistické skutečnosti. Autorka v nich pracovala se zážitkem z dětství, kdy podobně jako většina dětí poválečné generace měla panenky vyrobené $\mathrm{z}$ textilního odpadu. Její plastiky, které byly všechny ženského pohlaví, v sobě rovněž obsahovaly psychologický moment spojený s autorčinými vzpomínkami na dětství, ale i s otázkami vlastní identity - jednoho z hlavních témat feministického umění obecně. ${ }^{22}$

Kromě tematizace a kritiky domácí „ženské práce“ je s pojmem domova spojeno v oblasti feministického umění mimo jiné také téma pocitu uvěznění, tísně a nemožnosti aktivity. V Československu můžeme toto téma najít v malbě Petry Orieškové, která, ovlivněna pop-artem a novým realismem, nastoupila na výtvarnou scénu v polovině šedesátých let. V jejích obrazech šlo o konstrukci snového, symbolického světa a prostoru, v němž se skutečnost prolíná s fikcí a předměty a lidé jsou zde nositeli psychologických obsahů. Opakujícím se tématem pro ni byla osamělá, nahá a zranitelná ženská postava, která je uzavřena v chladných, pravoúhlých interiérech - např́klad v obraze Záměna je mladá dívka přirovnávána $\mathrm{k}$ divoké zvěři držené v zajetí. ${ }^{23}$ Kromě pocitu uvěznění je v její tvorbě obsažen i liberalizující moment. V malbě Útěk z roku 1974 zachytila Oriešková proces emancipace - vysvobození se z této nemožnosti pohybu a vlastní akce -, který se dost často jako ozdravný rituál objevoval i v akcích mnoha feministických autorek (například Donny Henes, Annegret Soltau $\left.{ }^{24}\right)$.

\section{Závěr}

Konflikt mezi soukromou a veřejnou rolí ženy je jedno $\mathrm{z}$ témat, které řešilo v šedesátých až osmdesátých letech feministické umění v socialistickém Československu stejně jako feministické umění na Západě. Československé umělkyně používaly v porovnání se západní feministickou tvorbou pro svá díla častěji tradičnější výtvarné formy jako objekt, malbu, grafiku a byly mimo jiné ovlivněny estetikou nové citlivosti, pop-artu a nové-

20 Srov. Jiří Valoch, Klára Bočkayová, Prešov 2005.

21 Jennie Klein, Feminist Art and Spirituality in the 1970s, Feminist Studies XXXV, 2009, č. 3, s. 575-602.

22 Ivan Jančár, Mira Haberernová Trančíková, Bratislava 2015, s. 78. - Richard Gregor, Haberernovej oko. Post-informálna figurácia v slovenskom výtvarnom umení 60. rokov 20. storočia, Bratislava 2012, s. 98.

23 Vlastimil Tetiva, Petra Oriešková (katalog výstavy), Wortnerův dům Alšovy Jihočeské galerie, 2002.

24 Viz Schor (pozn. 9), s. 39-42. 
ho realismu. Problematiku nerovného postavení žen ve společnosti řešily vycházivše ze své osobní zkušenosti. Oproti západním kolaborativním projektům se většinou jednalo o solitérní tvorbu, která nebyla kolektivně prožívaná. Nechut̉ umělkyň vưči kolektivním akcím žen a sdílení vlastních zkušeností vycházela $\mathrm{z}$ vymezování se vưči oficiální politice socialistického státu, jenž kolektivistický obraz a genderovou rovnost propagoval.

\section{SUMMARY}

\section{“The Personal is Political": The Feminist Fragments of Czechoslovak Fine Arts 1960s-1980s}

The article deals with several cases of Czechoslovak feminist art from the 1960s to the 1980s (art works of Klára Bočkayová, Mira Haberernová, Běla Kolářová, Petra Oriešková, Naděžda Plíšková, Zorka Ságlová). Although the second wave of feminism did not take place in socialist Czechoslovakia as it did in Western liberal democracies in the 1960s, and there was no feminist art movement politically activating the female artists, the feminist consciousness of many Czechoslovak female artists arose from their own experience of gender inequality at that time. One of the main themes that the female artists worked on in their works, and which also became a fundamental issue for contemporary gender policies, was the conflict between the domestic and public role of women. In comparison with Western feminist art production, the works of Czechoslovak female artists had more often more traditional forms such as objects, paintings, and graphics. In contrast to Western collaborative projects, it was mostly solitary creation, which was not collectively experienced. The artists' reluctance towards women's collective actions and the sharing of their own experiences was based on defining oneself towards the official policy of the socialist state, promoting the collectivist image and gender equality.

\section{VÝBĚROVÁ BIBLIOGRAFIE}

Norma Broude - Mary D. Garrard (eds), The Power of Feminist Art. The American Movement of the 1970s, History and Impact, New York 1996.

Amy Bryzgel, Performance art in Eastern Europe since 1960, Manchester 2017.

Bedřich Engels, Pưvod rodiny, soukromého vlastnictví a státu, Praha 1967.

Barbara Havelková, Tři stadia genderu v socialistickém právu, in: Hana Havelková - Libora Oates-Indruchová (eds), Vyvlastněný hlas. Proměny genderové kultury české společnosti 1948-1989, Praha 2015, s. $45-82$.

Marie Klimešová, Experiment, řád, dưvěrnost. Ženské rastry Běly Kolářové (katalog výstavy), Muzeum umění Olomouc, 2006.

Martina Pachmanová, Laying Diapers, Loving Nature: Maternity as a Private Act and Political Gesture, in: Katja Kobolt - Lana Zdravkovič (eds), Performative Gestures. Political Moves, Záhřeb 2014, s. 57-63.

Marianna Placáková, Člověk, nebo sexus? Diskuze k českému vydání knihy Simone de Beauvoir „Druhé pohlaví", Filosofický časopis LXVIII, 2020, č. 6, s. 865-886.

Piotr Piotrowski, The Politics of Identity: Male and Female Body Art, in: Piotr Piotrowski, In the Shadow of Yalta. Art and the Avant-garde in Eastern Europe, 1945-1989, Londýn 2011.

Gabriele Schor, Feministische Avantgarde. Kunst der 1970er-Jahre. Sammlung Verbund, Wien 2016.

Alena Wagnerová, Žena za socialismu [1974], Praha 2017. 


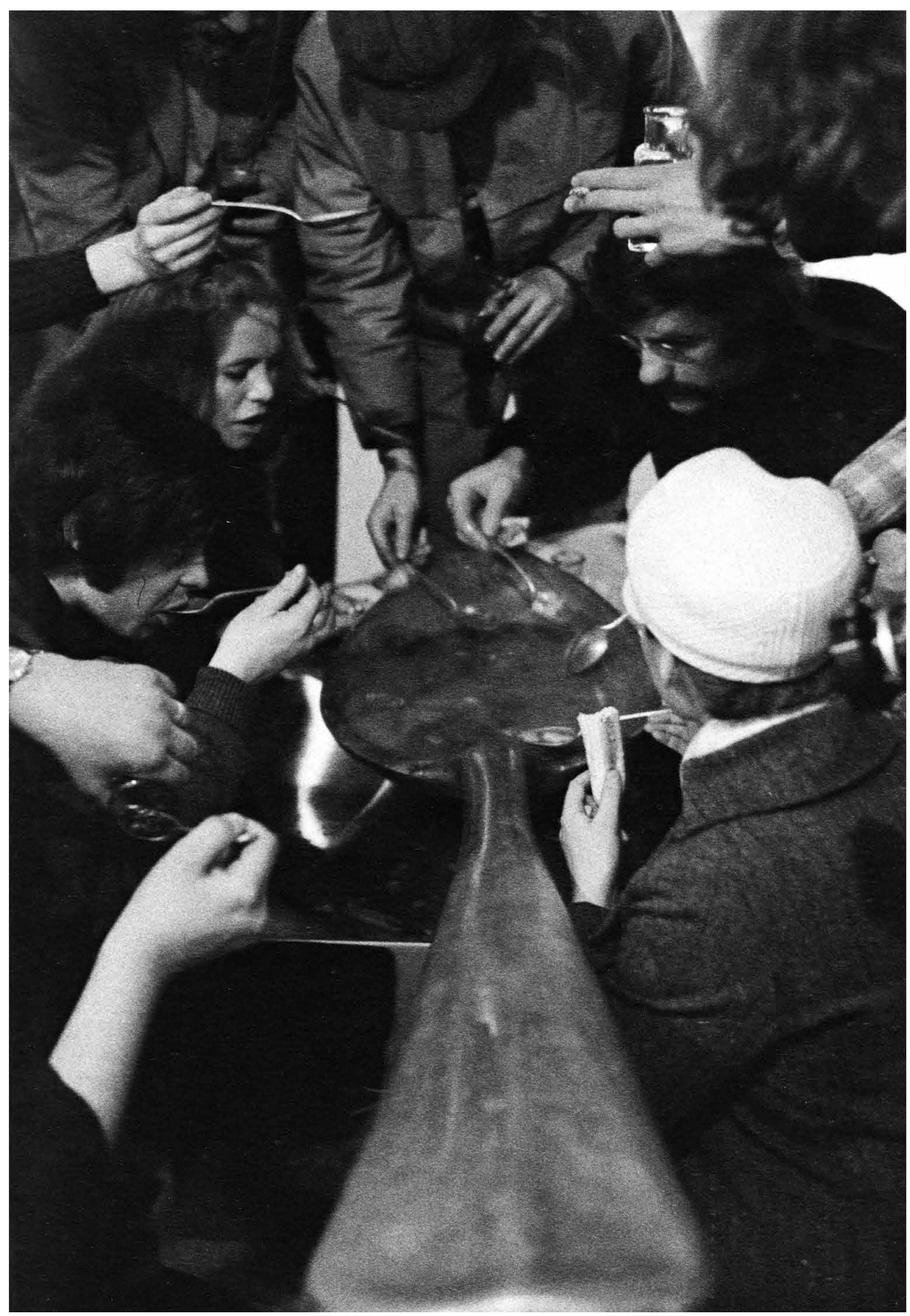

Obrázek 1. Naděžda Plíšková, 7 litrů gulášové polévky, 1970, Galerie Václava Špály, foto: Helena Wilson, archiv Karolíny Neprašové Kračkové. Reprodukce z katalogu Marianna Placáková, Já, Naděžda Plišková (katalog výstavy), Museum Kampa, 2019, s. 5 


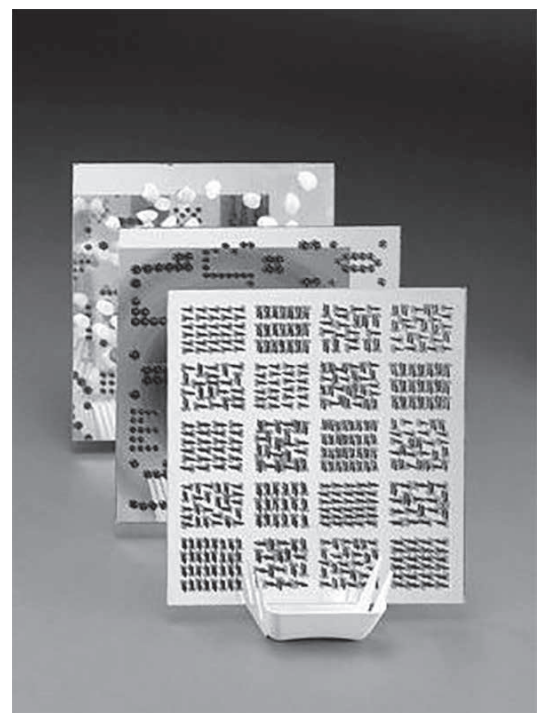

Obrázek 2. Běla Kolářová, Nádobí, 1966, asambláž. Reprodukce z katalogu Alice Motard - Marie Klimešová, Běla Kolářová (katalog výstavy), Raven Row, 2013, nestránkováno

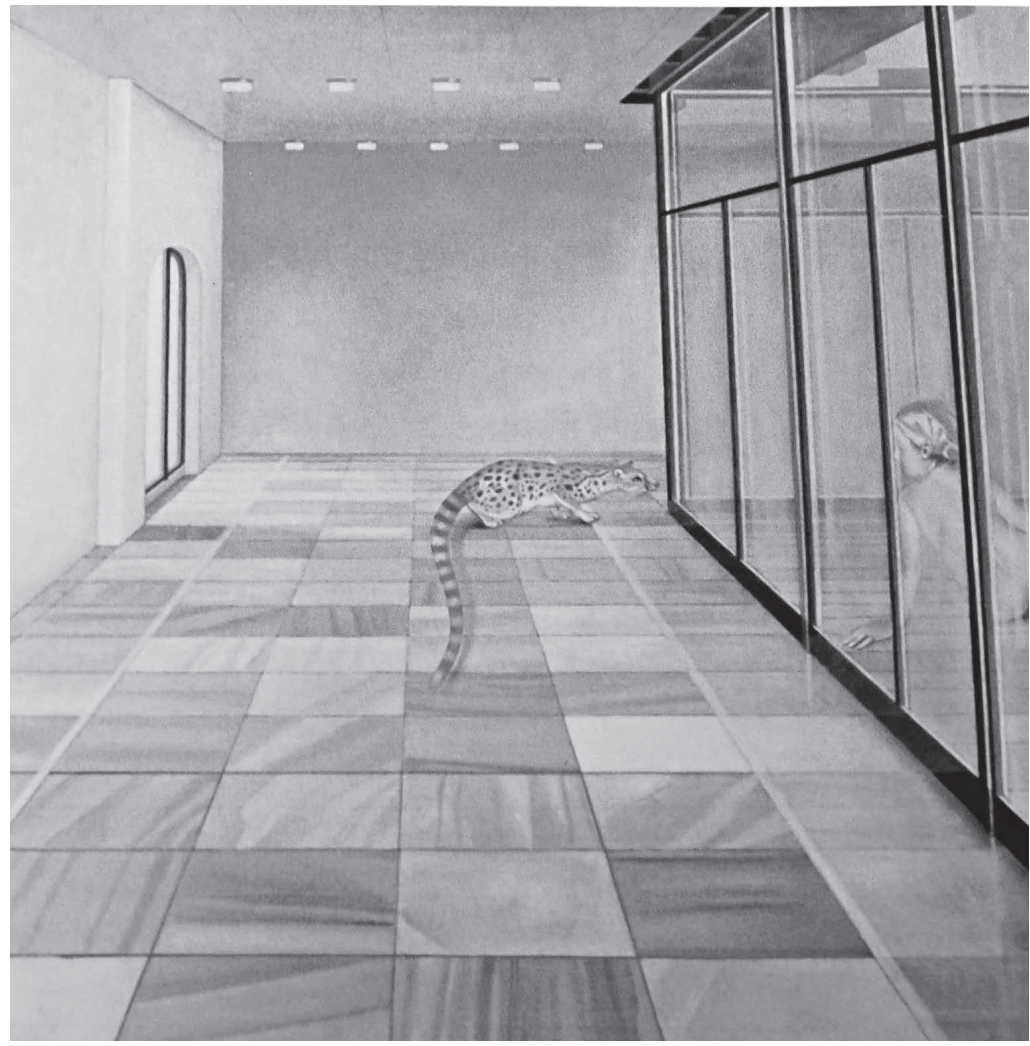

Obrázek 3. Petra Oriešková, Záměna, 1979, olejomalba, zdroj: Vlastimil Tetiva, Petra Oriešková. Obra$z y$ - kresby. Výběr z tvorby 1966-2001, České Budějovice 2002, nestr. 